\title{
Analysis of Energy Flows in an Intertidal Oyster Reef
}

\author{
Richard F. Dame ${ }^{1}$ and Bernard C. Patten ${ }^{2}$ \\ 'Belle W. Baruch Institute for Marine Biology and Coastal Research, University of South Carolina, Conway, South Carolina, \\ USA \\ ${ }^{2}$ The Institute of Ecology, University of Georgia, Athens, Georgia, USA
}

\begin{abstract}
Input-output flow analysis is adapted in a simplified manner to an intertidal oyster reef. Approximately $11 \%$ of the energy moving through the reef is cycled. The largest amount of recycling takes place in the detritus component. Control relations are derived which imply that the filter feeders and predators have major controlling influences on energy flow in other reef components.
\end{abstract}

\section{IJNTRODUCTION}

It was first postulated by Möbius (1877) that the organisms living together on an oyster reef were functionally related to form a community or biocoenose. In the intervening period, the study of interacting groups of organisms and their concurrent environment has developed into the concept of the ecosystem.

One of the interesting and comprehensive ways to increase our understanding of ecosystems is to study the flow of energy/matter between the various components of the system and between the system and the environment. Early investigators developed simple budgets or balance sheets for energy/matter transfers and numerous efficiency ratios were developed. In addition, because of the complexity of ecological systems the concept of trophic or feeding levels was devised by Lindeman (1942) as a possible simplification mechanism utilizing the laws of thermodynamics. More recently, Hannon (1973) adapted the input-output theory of economics to ecosystems to reveal a 'structure' of the system by demonstrating with energy' matter flows the direct and indirect dependence of each member of the system upon the others. Finn (1976) and Patten et al. (1976) have expanded Hannon's ideas to a formal methodology and theory for the analysis of flows in ecosystems. It is our purpose to present a new accounting of energy flux in the oyster reef system and to further develop flow analysis.

\section{OYSTER REEF CONCEPTUALIZATION}

Oyster reefs have long been recognized as a system of organisms interacting with themselves and with their estuarine environments. Oyster reefs influence estuaries both physically by removing suspended particulate matter and changing current patterns, and biologically by removing phytoplankton and producing large quantities of oyster biomass. In addition, the structure of the reef provides habitats for many estuarine organisms.

In the southeastern United States, most oyster reefs are intertidal because in the high salinity estuaries of this area marine predators such as oyster drills and boring sponges decimate subtidal oyster populations (Dame, 1976).

There is a tremendous amount of published and unpublished work on oysters, but the scientific literature is sparse on the oyster reef as a system. Although there is specuation on the structural and functional importance of these systems (Hedgpeth, 1957; Dame. 1976), little work has been done to synthesize existing information. The holistic approach to the analysis of ecosystems lends itself well to the synthesis and evaluation of existing data and to the development of new approaches and increased understanding of the structure and function of oyster reefs as systems.

In the conceptualization of any system, it is prudent to choose a level of complexity which is justified by the 


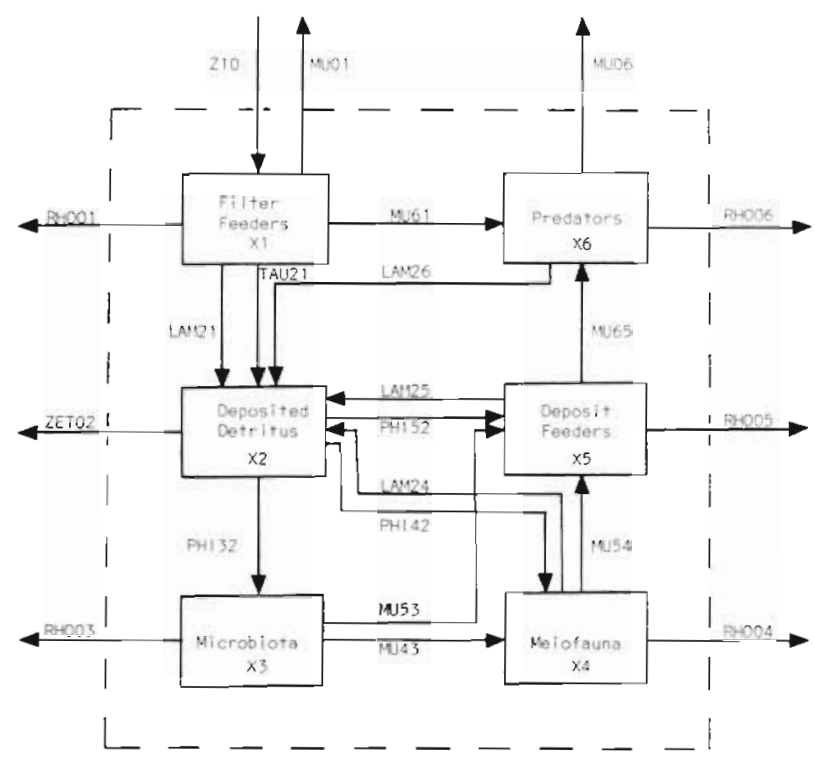

Fig. 1. Intertidal oyster reef model. Flows and components are defined in Tables 1 and 2. Numbers associated with each symbol denote a to/from relationship; for example, MU61 indicates mortality by predators $X 6$ on filter feeders $X 1$ or a flow to $X 6$ from $X 1$

available data. In the case of the oyster reef, the majority of the available information is in terms of energy units and because of this, biomass and flows will be expressed in terms of $\mathrm{Kcal} \mathrm{m}^{-2}$ and Kcal $\mathrm{m}^{-2} \mathrm{~d}^{-1}$ respectively. The oyster reef as conceived here (Fig. 1) has 6 major components; filter feeders, detritus, microbiota, meiofauna, deposit feeders, and predators. The definitions and documentation of these components and the flows interconnecting them and their environment are given in Tables 1 and 2 respectively.

The major components of the oyster reef are grouped according to feeding type and size. Filter feeders, deposit feeders, and predators are macroscopic organisms, while meiofauna and microbiota are progressively smaller living forms. The latter components group together diverse feeding types because little if any detailed information is available on their feeding relations.

The data presented in Tables 1 and 2 and Fire 2 essentially describe an energy budget for an intertidal oyster reef in South Carolina, USA. The average annual water temperature of $20^{\circ} \mathrm{C}$ is used for the oyster reef energy budget, and temperature dependent rates of flow are converted where necessary by $Q_{10}$ or graphical observation methods. For simplicity, the reef system model is assumed to obey the laws of thermodynamics and be in a steady state condition. This assumption has been supported over the past 10 years in the obsrvations of Dame $(1972,1976,1979)$.

This oyster reef consumes $41.5 \mathrm{Kcal} \mathrm{m} \mathrm{m}^{-2} \mathrm{~d}^{-1}$ or $15,137 \mathrm{Kcal} \mathrm{m} \mathrm{m}^{-2} \mathrm{y}^{-1}$, giving it one of the highest energy flows for a natural heterotrophic system. The filter feeders are the major component of the system by bringing energy into the reef via their coupling with the water column. This coupling allows the filter feeders to function both as grazers of phytoplankton and as suspended particulate detritus feeders. However, there is no evidence that filter feeders in the oyster reef utilize detritus as an energy source, but it is assumed they simply deposit this energy/matter which can then be used by other organisms.

\section{FLOW ANALYSIS}

Flow analysis is based on the ideas of cause and effect so common to science. Patten et al. (1976) have discussed and reviewed the foundations of cause in ecological systems. From these ideas, Hannon (1973), Finn (1976) and Patten et al. (1976) have developed a method of flow analysis as applied to ecological systems. In a system such as the oyster reef, causality is transmitted by conservative energy flows and at times by nonconservative information flows or at least flows

Table 1 Standing crops ( $\mathrm{Kcal} \mathrm{m}{ }^{-3}$ and $\mathrm{Kj} \mathrm{m}^{-2}$ ) for the intertidal oyster reef system

\begin{tabular}{|c|c|c|c|c|c|}
\hline \multirow[t]{2}{*}{ Symbol } & \multirow[t]{2}{*}{ Standing crop } & \multirow[t]{2}{*}{ Definution } & \multicolumn{2}{|c|}{ Value } & \multirow[t]{2}{*}{ Source } \\
\hline & & & $\mathrm{Kcal} \mathrm{m}^{-2}$ & $\mathrm{Kj} \mathrm{m}^{-2}$ & \\
\hline $\mathrm{x} 1$ & Filter feeders & $\begin{array}{l}\text { Oysters (Crassostrea virginica) and mussels } \\
\text { (Brachedontes exustus) }\end{array}$ & 2000.00 & 8368.00 & Dame $(1976,1979)$ \\
\hline $\mathrm{x} 2$ & Deposited detritus & $\begin{array}{l}\text { Particulate organic matter deposited in reef } \\
\text { sediments }\end{array}$ & 1000.00 & 4184.00 & Simon $(1976)$ \\
\hline$\times 3$ & Microbiota & Bacteria, yeast and fungi & 2.41 & 10.08 & Sikora et al. (1977) \\
\hline$\times 4$ & Meiofauna & $\begin{array}{l}\text { Animals passing through a } 1 \mathrm{~mm} \text { sieve and } \\
\text { retained on a } 0.063 \mathrm{~mm} \text { sieve }\end{array}$ & 24.12 & 100.92 & Sikora et al. (1977) \\
\hline$\times 5$ & Deposit feeders & Macrofauna feeding in the sediments & 16.27 & 68.07 & Dame $\{1979\}$ \\
\hline$x_{6}$ & Predators & $\begin{array}{l}\text { Predacious animals spending their adult lives in } \\
\text { the oyster reef system, mainly mud crabs }\end{array}$ & 69.24 & 289.70 & Dame (1979\} \\
\hline
\end{tabular}


Table 2. Energy flows (Kcal m $\mathrm{m}^{-2} \mathrm{~d}^{-1}$ and $\mathrm{Kj} \mathrm{m}^{-2} \mathrm{~d}^{-1}$ ) for the intertidal oyster reef system at $20^{\circ} \mathrm{C}$

\begin{tabular}{|c|c|c|c|c|c|}
\hline \multirow[t]{2}{*}{ Symbol } & \multirow[t]{2}{*}{ Flow } & \multirow[t]{2}{*}{ Defination } & \multicolumn{2}{|c|}{ Value } & \multirow[t]{2}{*}{ Source } \\
\hline & & & $\mathrm{Kcal} \mathrm{m}{ }^{-2} \mathrm{~d}^{-1}$ & $\mathrm{Kj} \mathrm{m}^{-2} \mathrm{~d}^{-1}$ & \\
\hline Z10 & Feeding & $\begin{array}{l}\text { Input of phytoplankton and suspended } \\
\text { particulate detritus by filter feeding }\end{array}$ & 41.47 & 173.51 & Tenore \& Dunstan (1973) \\
\hline $\mathrm{RHOO} 1$ & Respiration & Filter feeder respiration rate & 14.72 & 61.59 & Dame (1972) \\
\hline LAM21 & Egestion & Filter feeder feces & 5.92 & 24.77 & Tenore \& Dunstan (1973) \\
\hline TAU21 & Egestion & Filter feeder pseudofeces & 9.87 & 41.30 & Mackin (1962) \\
\hline MU61 & Mortality & $\begin{array}{l}\text { Filter feeder mortality due to inernal reef } \\
\text { predation }\end{array}$ & 0.51 & 2.13 & Dame (1976) \\
\hline MU01 & Mortality & $\begin{array}{l}\text { Filter feeder mortality due to transient } \\
\text { predators }\end{array}$ & 10.44 & 43.68 & $\cdot$ \\
\hline ZET02 & Resuspension & Resuspension of deposited organic material & 6.18 & 28.86 & $\cdot$ \\
\hline PHI32 & Feeding & $\begin{array}{l}\text { Feeding rate of microbiota on desposited } \\
\text { material }\end{array}$ & 8.17 & 34.18 & $\cdot$ \\
\hline PHI42 & Feeding & $\begin{array}{l}\text { Meiofaunal feeding on deposited detritus } \\
\text { with an assimilation efficiency of } 50 \% \text { on } \\
\text { total meiofaunal feeding }\end{array}$ & 7.27 & 30.42 & Gerlach (1971) and $\cdot$ \\
\hline PHI52 & Feeding & $\begin{array}{l}\text { Feeding rate of deposit feeders on deposited } \\
\text { detritus. An assimilation efficiency of } 24 \% \text { of } \\
\text { total feeding is used }\end{array}$ & 0.64 & 2.68 & Tenore \& Gopalan (1974) \\
\hline $\mathrm{RHO} 03$ & Respiration & Microbiota respiration rate & 5.76 & 24.10 & Teal \& Kanwisher (1961) \\
\hline MU43 & Feeding & Feeding rate of meiofauna on microbiota & 1.21 & 5.06 & Rheinheimer (1977) \\
\hline MU53 & Feeding & $\begin{array}{l}\text { Feeding rate of deposit feeders on } \\
\text { microbiota }\end{array}$ & 1.21 & 5.06 & $\cdot$ \\
\hline $\mathrm{RHO} 4$ & Respiration & Meiofaunal respiration rate & 3.60 & 15.06 & $\begin{array}{l}\text { Wieser \& Kanwisher } \\
(1961) ; \text { Vernberg } \\
\& \text { Coull }(1974)\end{array}$ \\
\hline LAM24 & Egestion & Meiofaunal egestion rate & 4.24 & 17.74 & $\cdot$ \\
\hline MU54 & Feeding & $\begin{array}{l}\text { Deposit feeders feeding rate on meiofauna } \\
\text { was assumed equal to meiofaunal } \\
\text { production of } 10 \text { biomass turnovers/year }\end{array}$ & 0.66 & 2.76 & Gerlach (1971) \\
\hline RHOO5 & Respiration & Deposit feeder respiration rate & 0.43 & 1.80 & Dame (1977) \\
\hline MU65 & Feeding & $\begin{array}{l}\text { Reef predator feeding rate on deposit feeder } \\
\text { production }(P / R=0.4)\end{array}$ & 0.17 & 0.71 & Tenore \& Gopalan (1974) \\
\hline LAM25 & Egestion & Egestion rate of deposit feeders & 1.91 & 7.99 & $\cdot$ \\
\hline RHO06 & Respiration & Reef predator respiration rate & 0.30 & 1.26 & Dame \& Vernberg (1978) \\
\hline MU06 & Mortality & $\begin{array}{l}\text { Reef predator mortality due to transient } \\
\text { predators }(\mathrm{P} / \mathrm{R}=0.18)\end{array}$ & 0.05 & 0.21 & Dame (unpubl.) \\
\hline LAM26 & Egestion & Egestion rate of predators & 0.33 & 1.38 & $\cdot$ \\
\hline
\end{tabular}

that are similar to informational or cybernetic controls. In this type of system, input/output flow analysis permits the tracing of relationships within the system. Thus the use of flow analysis allows us to describe the internal flow structure of the system. This structure can show us how much energy is flowing through the system versus how much is cycling within the system. Energy cycling is used here to mean that some potential energy is not utilized on its first pass through a component.

In flow analysis, the initial procedure is to 'nor- malize' in turn one unit of output from each component in the reef system. Back calculation from an output determines the source flows necessary to produce a given unit of output. These source flows are specific for each unit of outflow and are called input environments (Fig. $3 \mathrm{~A}-\mathrm{F}$ ). Numbers within a component are the throughflows required to generate a unit of outflow; numbers associated with arrows represent causal flows such as feeding or respiration. The sum of the input or output flows to a given component defines the throughflow value $\left(T_{11}\right)$. To express the normalized 


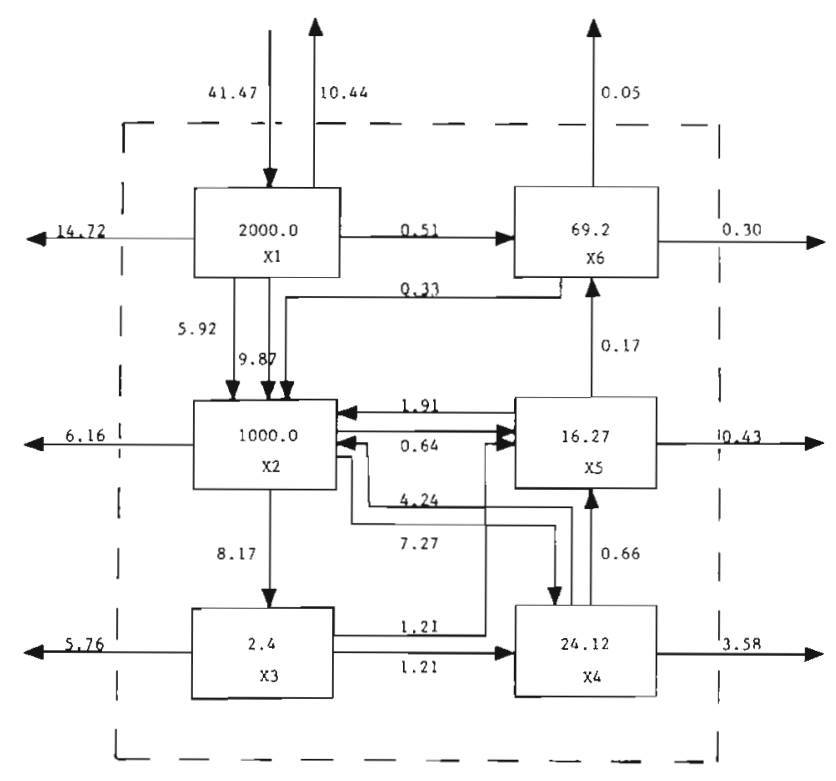

Fig. 2. Energy flows (Kcal m${ }^{-2} \mathrm{~d}^{-1}$ ) and standing crops (Kcal $\mathrm{m}^{-2}$ ) in an intertidal oyster reef

environments as energy flows (Kcal $\mathrm{m}^{-2} \mathrm{~d}^{-1}$ ), the numbers in Figure $3 \mathrm{~A}-\mathrm{F}$ must be multiplied by the corresponding output flux as given in Figure 2.

The values for the input environments are described in Figure $3 \mathrm{~A}-\mathrm{F}$. In the simplest input environment case, one unit of output from X1 (filter feeders) requires one unit of input to X1 and this generates one unit of throughflow (Fig. 3 A). All the energy flow takes place in X1. A more complicated case is shown in Figure $3 \mathrm{~F}$. One unit of output from $\mathrm{X} 6$ (predators) requires 0.753 units from $X 1$ and 0.252 units from $X 5$. In addition, 0.005 units flow from $X 6$ to $X 2$. This results in a throughflow of 1.005 for $X 6$. Because the only input to the reef system is via $X 1$, one unit inputs at that point.

There are 6 real input environments in the model because each component is connected to the external reef environment by an output. In the output case, there is only 1 real environment because the only real input to the model system is via X1. All other output environments are imaginary because they are not defined in the model, but the imaginary environments are necessary for certain flow analysis computations. The single real output environment and the 5 imag.nary environments are given in Figure $4 \mathrm{~A}-\mathrm{F}$. In the real case, one unit of input generates the flows shown in Figure $4 \mathrm{~A}$. These flows can easily be calculated by dividing each flow in Figure 2 by 41.47 (e.g. 'normalizing'). Throughflows are calculated as the sum of the inputs to or from a given component.

In order to calculate the imaginary output environments without using matrix mathematics, it is helpful to know that the throughflow for a given component in the like number input environment is equal to the throughflow for the same component in the like number output environment. Thus, component $X 3$ of Figure $3 \mathrm{C}$ has the same throughflow as component $\mathrm{X} 3$ of Figure $4 \mathrm{C}$. In addition to the preceding, the proportion or fraction of any flow compared to the input flow can be calculated from Figure 1. Combining the information on throughflow with the information on fractional flow allows us to generate the imaginary environments in Figure $4 \mathrm{~A}-\mathrm{F}$.

\section{FLOW ANALYSIS MEASURES}

There are a number of characteristics at steadystate of flow analysis. These characteristics are pathlength, cycling efficiency, and cycling index. These quantities are all useful in comparing the structure and functional traits of different ecological systems. Each of these characteristics will be derived in the following discussion.

Unnormalized throughflow is the amount of energy/ matter passing through each component on an average day. The value is derived by simply summing the inputs or outputs for a given component as described in Figure 2. Because the oyster reef model conforms to the laws of thermodynamics, throughflow observed for each component declines as energy moves through the system (Table 3 ). Total system throughflow (TST) is the sum of the unnormalized individual throughflows and in this case is $83.58 \mathrm{Kcal} \mathrm{m}^{-2} \mathrm{~d}^{-1}$.

The average pathlength of an inflow (APLZ) is defined as the average number of compartments through which a given inflow passes (Finn, 1976). For

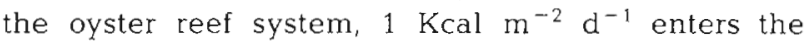
system via the filter feeders $X 1$ and has a pathlength of 1.0 while traversing $X 1$ (Fig. 4 A). Only $39 \%$ of the input to X1 moves on to other components in the reef while $61 \%$ leaves the system as respiration and egestion. The $39 \%$ portion which moves on to other compartments will have a pathlength of at least 2.0 and $24 \%(0.381-0.149)$ will have a pathlength of 3.0. The end result is an average pathlength of an inflow of 2.02 which is the sum of the throughflows (Ti) for a given input environment (e.g. Fig. 4 A). Imaginary average pathlengths of an inflow can be calculated in a like manner for inputs from outside the system to components $\mathrm{X} 2-\mathrm{X} 6$ and these are given in Table 3 .

The average pathlength of a unit of outflow (APLY) from a given compartment is derived similarly to

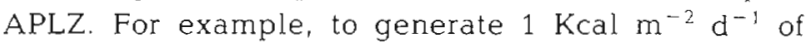
outflow from $\mathrm{X} 1,1 \mathrm{Kcal} \mathrm{m}^{-2} \mathrm{~d}^{-1}$ must enter the system and pass completely through $X 1$ and out of the system (Fig. $3 \mathrm{~A}$ ). This yields $1 \mathrm{Kcal} \mathrm{m} \mathrm{m}^{-2} \mathrm{~d}^{-1}$ of throughflow and likewise an average pathlength of a unit of outflow of 1.0. Also, by summing the throughflows of each 

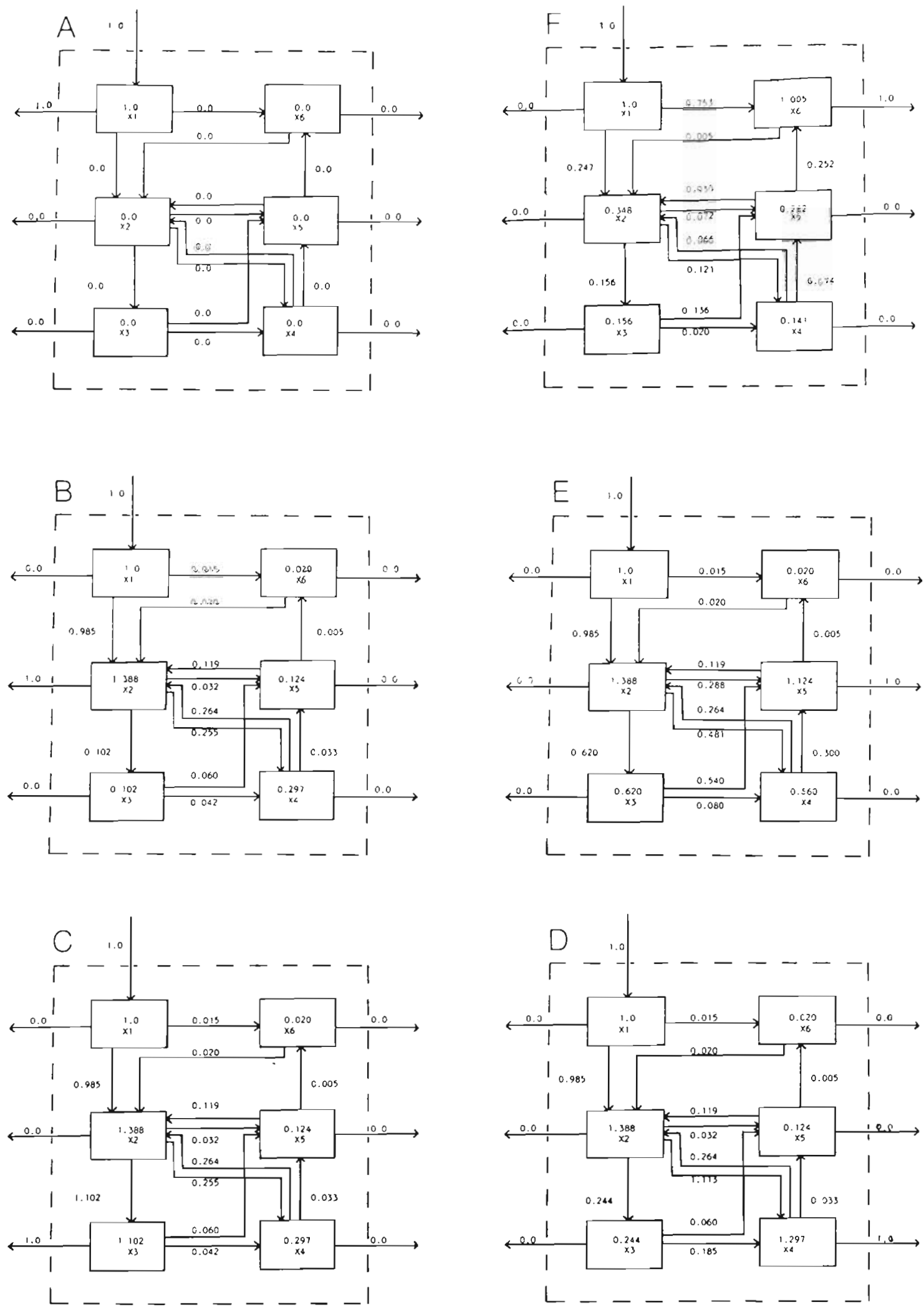

Fig. 3. Input environments for the intertidal oyster reef energy flow model. Numbers in boxes are throughflows (Ti). A-F see text 

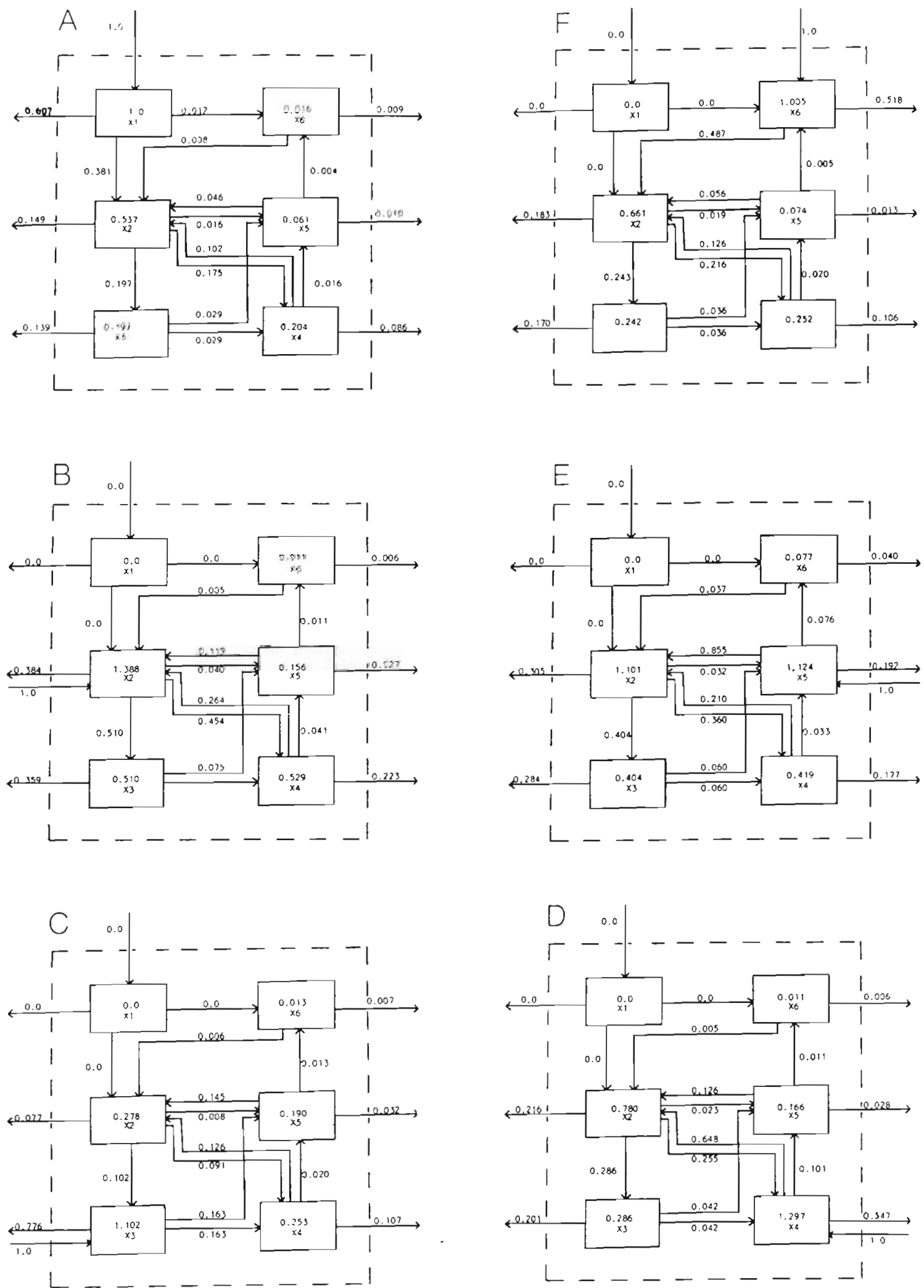

Fig. 4. Output environments for the intertidal oyster reef energy flow model. Numbers in boxes are throughflows (Ti). A-F see text 
Table 3. Flow analysis measures

\begin{tabular}{|c|c|c|c|c|c|c|}
\hline \multirow[b]{2}{*}{ Measure } & \multirow[b]{2}{*}{$\begin{array}{l}\text { Filter feeders } \\
\qquad(\mathrm{X} 1)\end{array}$} & \multirow[b]{2}{*}{$\begin{array}{l}\text { Detritus } \\
\text { (X2) }\end{array}$} & \multicolumn{2}{|c|}{ State } & \multirow[b]{2}{*}{$\begin{array}{c}\text { Deposit } \\
\text { feeders }(\mathrm{X} 5\}\end{array}$} & \multirow[b]{2}{*}{$\begin{array}{l}\text { Predators } \\
\qquad(\mathrm{X} 6)\end{array}$} \\
\hline & & & $\begin{array}{l}\text { Microbiota } \\
\text { (X3) }\end{array}$ & $\begin{array}{c}\text { Meiofauna } \\
(\mathrm{X} 4)\end{array}$ & & \\
\hline Throughflow (Ti) & 41.47 & 22.27 & 8.17 & 8.48 & 2.51 & 0.69 \\
\hline Average pathlength of a unit input (APLZ) & 2.02 & 2.59 & 1.84 & 2.54 & 3.12 & 2.23 \\
\hline Average pathlength of a unit output (APLY) & 1.00 & 2.93 & 3.93 & 4.07 & 4.71 & 2.93 \\
\hline$\%$ Total system throughflow-inflow & 100.00 & - & - & - & - & - \\
\hline$\%$ Total system throughflow-outflow & 30.10 & 21.66 & 27.10 & 17.45 & 2.43 & 1.26 \\
\hline Recycling efficieney (RE) & 0.00 & 0.28 & 0.09 & 0.23 & 0.11 & 0.01 \\
\hline \multicolumn{7}{|c|}{$\begin{array}{l}\text { Total system throughflow }(\mathrm{TST})=83.58 ; \text { Total system throughflow straight (TSTs) }=74,33 \text {; Total system throughflow cycled } \\
(\mathrm{TSTC})=9.21 \text {; Average pathlength }(\mathrm{APL})=2.02 \text {; Average pathlength straight }(\mathrm{APLS})=1.79 \text {; Average pathlength cycled } \\
\text { (APLc) }=0.22 ; \text { Cycling index ( } \mathrm{TST} / \mathrm{TST}=\mathrm{CI})=0.11\end{array}$} \\
\hline
\end{tabular}

component for a given outflow environment an APLY can be calculated for each component (Table 3).

The average pathlength for an average inflow into the reef model is the total system throughflow (83.58) divided by the inflow Z (41.47) and is 2.02 for the oyster reef system. In the oyster reef system, all energy does not move directly or straight through the system, some energy is cycled. Energy cycling does not mean energy is degraded more than once, but that some potential energy is not utilized on its first pass through a component and a small proportion of that energy may be recycled back to a component it has already passed through. Energy cycling is particularly common in the sediments where deposit feeding organisms are constantly ingesting and egesting partially decomposed material. Thus in the oyster reef system, cycling pathways are found among the deposited detritus $X 2$, microbiota X3, meiofauna X4, deposit feeders X5, and predators X6.

A recycling efficiency ( $R E$ ) may be calculated for a given component by subtracting 1.0 unit of flow from the throughflow for that particular component in the outflow environment for that component $\left(T_{11}-1.0\right)$ and dividing by the same throughflow $\left(T_{11}\right)$.

$$
R E=\left(T_{11}-1.0\right) / T_{11}
$$

For component $\mathrm{X} 2$ (Fig. $3 \mathrm{~B}$ ), recycling would be

$$
R E=(1.388-1.0) / 1.388=0.288
$$

and indicates that $28.8 \%$ of the energy entering the deposited detritus eventually returns. The recycling efficiencies for the other components of the oyster reef system are given in Table 3 . From the preceding discussion of recycling efficiency, it is implied that total system throughflow (TST) is composed of a cycled (TSTc) and a noncycled or straight (TSTs) portion

$$
\mathrm{TST}=\mathrm{TST}_{\mathrm{C}}+\mathrm{TSTs}
$$

By multiplying the appropriate recycling efficiency (RE) in Table 3 by the throughflow $\left(\mathrm{T}_{\mathrm{ii}}\right)$ for a given component, the portion of throughflow due to cycling can be calculated. Summing the cycling portions yields total system throughflow which cycles (TSTc) and by subtraction, the energy which moves directly through the system (TSTs). In the case of oyster reef system, total system throughflow which cycles is 9.21 Kcal $\mathrm{m}^{-2} \mathrm{~d}^{-1}$. In addition, average pathlength for straight and cycled flows may be calculated and are 1.79 and 0.22 respectively. Finally, a dimensionless cycling index (CI) may be calculated by dividing cycled throughflow (TSTC) by total system throughflow (TST). The cycling index for the oyster reef system is 0.11 .

\section{CONTROL}

Hutchinson (1948) first pointed out the significance of biogeochemical cycling in ecosystems and that nutrient cycles linked ecosystem components together in a circular causal network. Patten et al. (1976) have shown that circular causal networks or loops in ecosystems confer the property that all ecosystem components are mutually causally dependent. Essentially every ecosystem component affects and is affected by every other directly or indirectly.

Closed ecosystem causal networks or feedback loops represent a potential for controlling the system (Patten, 1979). In addition, the 'law of maximum energy' (Lotka, 1925), later expanded to the maximum power principal (energy flow) by Odum and Pinkerton (1955), supports the notion of higher energy flows dominating lower energy flows through time. In a circular causal system, one component will control another if its influence, in terms of energy flow, on the latter is greater than the latter's influence on it. Thus, Xi controls $\mathrm{Xj}$ if the direct and indirect energy flow from $X i$ to $X j$ exceeds that from $\mathrm{Xj}$ to $\mathrm{Xi}$. Control relationships as a result of energy flow can be established by comparing the energy environments of $\mathrm{Xi}$ and $\mathrm{Xj}$. 
Table 4. Control matrix for oyster reef model

\begin{tabular}{|c|c|c|c|c|c|c|c|}
\hline & $i \backslash j$ & $\begin{array}{c}\text { Filter } \\
\text { feeders } \\
\text { X1 }\end{array}$ & $\begin{array}{c}\text { Deposited } \\
\text { detritus } \\
\times 2\end{array}$ & $\begin{array}{c}\text { Microbiota } \\
\times 3\end{array}$ & $\begin{array}{l}\text { Meiofauna } \\
\qquad 44\end{array}$ & $\begin{array}{l}\text { Deposit } \\
\text { feeders } \\
\times 5\end{array}$ & $\begin{array}{c}\text { Predators } \\
\text { X6 }\end{array}$ \\
\hline Filter feeders & $\times 1$ & $\begin{array}{c}1.00 / 1.00 \\
1.00\end{array}$ & $\begin{array}{c}0.00 / 1.00 \\
0.00\end{array}$ & $\begin{array}{c}0.00 / 1.00 \\
0.00\end{array}$ & $\begin{array}{c}0.00 / 1.00 \\
0.00\end{array}$ & $\begin{array}{c}0.00 / 1.00 \\
0.00\end{array}$ & $\begin{array}{c}0.00 / 1.00 \\
0.00\end{array}$ \\
\hline Deposited detritus & $\times 2$ & $\begin{array}{c}0.54 / 0.00 \\
\propto\end{array}$ & $\begin{array}{c}1.39 / 1.39 \\
1.00\end{array}$ & $\begin{array}{c}0.29 / 1.39 \\
0.20\end{array}$ & $\begin{array}{c}0.78 / 1.39 \\
0.56\end{array}$ & $\begin{array}{c}1.10 / 1.39 \\
0.79\end{array}$ & $\begin{array}{c}0.66 / 0.35 \\
1.90\end{array}$ \\
\hline Microbiota & $\times 3$ & $\begin{array}{c}0.20 / 0.00 \\
\infty\end{array}$ & $\begin{array}{c}0.51 / 0.10 \\
5.00\end{array}$ & $\begin{array}{c}1.10 / 1.10 \\
1.00\end{array}$ & $\begin{array}{c}0.29 / 0.24 \\
1.17\end{array}$ & $\begin{array}{c}0.40 / 0.62 \\
0.65\end{array}$ & $\begin{array}{c}0.24 / 0.16 \\
1.55\end{array}$ \\
\hline Meiofauna & $\times 4$ & $\begin{array}{c}0.20 / 0.00 \\
x\end{array}$ & $\begin{array}{c}0.53 / 0.30 \\
1.78\end{array}$ & $\begin{array}{c}0.25 / 0.30 \\
0.85\end{array}$ & $\begin{array}{c}1.30 / 1.30 \\
1.00\end{array}$ & $\begin{array}{c}0.42 / 0.56 \\
0.75\end{array}$ & $\begin{array}{c}0.25 / 0.14 \\
1.79\end{array}$ \\
\hline Deposit feeders & X5 & $\begin{array}{c}0.61 / 0.00 \\
\infty\end{array}$ & $\begin{array}{c}0.16 / 0.12 \\
1.26\end{array}$ & $\begin{array}{c}0.19 / 0.12 \\
1.53\end{array}$ & $\begin{array}{c}0.17 / 1.12 \\
1.34\end{array}$ & $\begin{array}{c}1.12 / 2.12 \\
1.00\end{array}$ & $\begin{array}{c}0.07 / 0.28 \\
0.26\end{array}$ \\
\hline Predators & $\mathrm{X} 6$ & $\begin{array}{c}0.02 / 0.00 \\
\infty\end{array}$ & $\begin{array}{c}0.01 / 0.02 \\
0.55\end{array}$ & $\begin{array}{c}0.01 / 0.02 \\
0.65\end{array}$ & $\begin{array}{c}0.01 / 0.02 \\
0.55\end{array}$ & $\begin{array}{c}0.08 / 0.02 \\
3.85\end{array}$ & $\begin{array}{c}1.01 / 1.01 \\
1.00\end{array}$ \\
\hline
\end{tabular}

Conceptually, the oyster reef system (Fig. 1) has a number of causal loops between $\mathrm{X} 2, \ldots, \mathrm{X} 6$. There is no feedback to $X 1$, and the influence by $X 1$ via energy flow over all other components in the reef is obvious and absolute. The ten feedback loops encompassing $\mathrm{X} 2, \ldots, \mathrm{X} 6$ give this system a number of interesting patterns of mutual dependency.

Patten (1979) has noted that if a system is circularly causal, then every component will appear in both the input and output environments of every other component because of the mutual dependency property. For component $\mathrm{X}_{\mathrm{i}}$ to be controlling on $\mathrm{X}_{\mathrm{j}}$ it must be more important in the input environment $\mathrm{Ej}^{\prime}$ than in the output environment $\mathrm{Ej}^{\prime \prime}$. Likewise, $\mathrm{Xj}$ will be more important in the output environment $\mathrm{Ei}^{\prime \prime}$ than in the input environment $\mathrm{Ei}^{\prime}$ of $\mathrm{Xi}$.

For a system like the oyster reef which we have described in terms of energy, the total energy flowing through a component as given by the throughflow Tij is a measure of importance in an input or output environment. Thus, the comparison of Tij' through component $\mathrm{Xi}$ in input environment $\mathrm{Ej}^{\prime}$ of $\mathrm{Xj}$, and $\mathrm{Tij}^{\prime \prime}$ through $\mathrm{Xi}$ in output environment $\mathrm{Ej}^{\prime \prime}$ is an estimate of control on $\mathrm{Xi}$. For example, in Figure $3 \mathrm{~F}$, the inflow environment $E 6^{\prime}$ is shown for a normalized unit outflow from component $\mathrm{X} 6$, the predators. The throughflows for this environment are $T 16^{\prime}=1.0$, $\mathrm{T} 26^{\prime}=0.348, \ldots$, and $\mathrm{T}^{\prime} 6^{\prime}=1.005$. Also, in Figure $4 \mathrm{~F}$ the outflow environment $\mathrm{E}^{\prime \prime}$ is shown for a normalized inflow (imaginary) to component X6. The throughflows for this outflow environment are $\mathrm{T} 16^{\prime \prime}=0.0$, T26" $=0.661, \ldots$, and $\mathrm{T} 66^{\prime \prime}=1.005$. To determine the control or compare importance relationships between any two components $\mathrm{Xi}$ and $\mathrm{Xj}$, control elements may be defined as

$$
\mathrm{Cij}=\mathrm{Tij}^{\prime \prime} / \mathrm{Tij}^{\prime}
$$

The numerator expresses the importance of $\mathrm{Xi}$ in the output environment of $\mathrm{Xj}$ and the denominator expresses the importance of $\mathrm{Xi}$ in the input environment of $\mathrm{Xj}$. If $\mathrm{Cij}>1, \mathrm{Xi}$ controls $\mathrm{Xj}$; if $\mathrm{Cij}=1$, control is neutral; if $\mathrm{Cij}<1, \mathrm{Xj}$ controls $\mathrm{Xi}$. Thus, control $\mathrm{C} 16=\mathrm{T} 16^{\prime \prime} /$ $\mathrm{T} 16^{\prime}=0.0 / 1.0=0.0$ which indicates absolute control of X1 over X6.

The control relations shown in Table 4 for the oyster reef system show that the filter feeders $\mathrm{X} 1$ control all other components because all control values for $\mathrm{X} 2, \ldots, \mathrm{X} 6$ are 0.0 as indicated in row one. Likewise the reciprocal is true in that the values for $X 2, \ldots, X 6$ in column one are all infinity. These control relations are obvious because inspection of the flow network shows there is no feedback via energy flow to the filter feeders from other components in the system. The control value for $\mathrm{Xi}$ with regard to itself, is neutral or 1.0 , because $\mathrm{Xi}$ is always equally important in its output environment $\mathrm{Ei}^{\prime \prime}$ per unit input as in its input environment Ei' per unit input.

Deposited detritus $\mathrm{X} 2$, the only non-living component, is controlled by filter feeders and predators while the deposit dwelling organisms, microbiota, meiofauna and deposit feeders, are controlled by deposited detritus.

The microbiota $X 3$, Row 3 , are controlled by filter feeders, deposited detritus, meiofauna and predators while the microbiota control deposit feeders. The meiofauna X4, Row 4, control microbiota and deposit feeders, but are controlled by filter feeders, deposited detritus and predators. The deposit feeders, Row 5, are controlled by all other components except the predators which they control.

The predators, Row 6, control deposited detritus, microbiota, and meiofauna. The latter two controls are particularly interesting because they are indirect and 
seem to support the ecological argument for top level consumer control of the environment.

\section{DISCUSSION}

The intertidal oyster reef, as conceptualized here, is a strongly heterotrophic system utilizing tidal energy to bring in food and carry away waste material. The energy/matter deposited by the filter feeders is processed by a subsystem of organisms living in the sediments thus increasing the efficiency of energy/matter utilization by the reef as a whole.

Analysis of input/output environments generated by normalized inputs and outputs reveals the internal structure of the model. This detailed internal structure shows the separation of the filter feeder component from the rest of the system because there are no feedback energy flows to the filter feeders from other components in the system. The structure of flows in the sediment portion of the reef reveals numerous feedback loops which can influence the processes in these components.

The measures of flow analysis derived from the various input and output environments offer additional information about the oyster reef system. Total system throughflow (TST) is slightly twice as large as the energy entering the system, but TST is a function of the number of components and not a good measure for comparative purposes (Finn, 1976). However, the subdivision of TST into straight and cycled components allows the computation of the cycling index (CI) which has no units and which can be used to compare systems. Surprisingly, $11 \%$ of the energy moving through the reef system cycles and this cycling occurs in the components making up the sediment subsystem. The cycling index is also a measure of how far a flow penetrates or comes out of a system (Patten et al., 1976). It appears from the oyster reef $\mathrm{Cl}$ that the majority of energy/matter flow entering or leaving the oyster reef is surficial (filter feeders, detritus and predator components), and not deeply imbedded in food web networks. This idea is reinforced by a short average pathlength value of 2.02 .

Another observation from total system throughflow is the percent TST leaving the system via each component. In the oyster reef system, the outflows except in the case of detritus and transient predators are measures of metabolic work, i.e. respiration. From this point of view, the filter feeders are doing a lot of metabolic work, but the microbiota and meiofauna are also important in total system energy degradation (:r entropy production.

The average pathlength of a flow recognized to produce an output from a given component (APLY) indi- cated the microbiota, meiofauna and deposit feeders are most deeply imbedded from the external environment with a given input flow traveling about 4 pathlengths before entering them. Patten et al. (1976) have suggested that APLZ is a measure of relative causal strength in a circularly causal system, that is, the number of compartments an inflow passes through. In the oyster reef model, the only APLZ is the inflow via the filter feeders.

The recycling efficiency (RE) of each component reflects the proportion of energy/matter which has been in a given compartment which passes through that compartment again or is recycled. In the oyster reef model, recycling efficiency is highest in the deposited detritus and meiofauna, but is significant in the deposit feeders and microbiota. High RE is expected in a depositional environment where numerous organisms are feeding on and recycling the same sediments.

The analysis of control relations in the oyster reef system offers some interesting possibilities. The control of all components in the reef system by the filter feeders has already been suggested from normalized flow diagrams and observations of feedback loops. Ecologically it is obvious that the filter feeders are the reason the reef is called an oyster reef, and the absence of the filter feeders makes the system a mud flat. What is not so obvious is the control of three components by the predatory mud crab component. Mud crabs are a major predator of young oysters. Such predation probably would reduce the filtration rate of the filter feeders and in turn would reduce the amount of energy/ matter entering the deposited detritus component. In addition, mud crabs produce waste which flow to the deposited detritus component. The control relations also indicate that the predators exhibit via energy flow some control over the microbiota and meiofauna which must be through indirect means. Again invoking the idea of the circular causal system (Hutchinson, 1948), it is possible to envision the deposited detritus already controlled by the predators also translating control of the predators over the microbiota and meiofauna. This reasoning is supported by the control relations for the deposited detritus which indicate this component controlling the microbiota and meiofauna as well as the deposit feeders. Another implication of the control analysis of energy/matter flows for the predator component is that the predators are food limited, i.e. controlled by their food resources, filter feeders and deposit feeders.

The regulation of systems by consumers has been discussed at length by Kitchell et al. (1979), and by filter feeders in particular by Dame et al. (1980). These authors point out that filter feeders regulate nutrient cycling and energy flow in ecosystems through translocation and transformation of matter. The analysis of 
flows and control relations reaffirm filter feeder regulation in oyster reefs. O Neill (1976) has noted that the regulatory function of heterotrophs is probably not represented by standing crop or energy flow alone, and the analysis of the oyster reef model supports this idea. Predators are only a very small portion of the rec $f$ system, but their influence through control seems important. There is experimental field evidence (Virnstein, 1979) that predatory crabs in shallow estuarine environments do influence the biomass and diversity of prey organisms. The results of control analysis on the oyster reef model are provocative and suggest numerous field or microcosm experiments to test the validity of predator control in this system.

Flow analysis, as described here, has allowed a much more detailed picture of energy/matter flow in the intertidal oyster reef. Important components and flows are more clearly recognized through this approach and the structural and functional reasons for their importance are suggested. Finally, hypotheses and experiments are made evident by the analysis and these can only lead to a better understanding of ecological systems.

Acknowledgements. The senior author wishes to thank The Institute of Ecology at the University of Georgia for space and computer time to conduct this work while on sabbatical leave. We wish to thank Dr T Foin, University of California at Davis and Dr. Clay Montague, University of Florida for critically reading the manuscript. Stuart Stevens of the University of Georgia Marine Institute was very helpful in the discussion and development of many of the points discussed in this paper This is publication No. 387 of the Belle W. Baruch Institute for Marine Biology and Coastal Research.

\section{LITERATURE CITED}

Dame, R. F. (1972). The ecological energies of growth, resp1ration, and assimilation in the American oyster, Crassostrea virginica. Mar Biol. 17: 243-250

Dame, R. F. (1976). Energy flow in an intertidal oyster population. Estuar coast. mar Sci. 4: 243-253

Dame, R. F. (1977). The macrobenthic fauna of North Inlet: abundance, diversity, and respiration. In: Vernberg, F. J (ed.) The dynamics of an estuary as a natural ecosystem. EPA-600-3-77-616, Washington, D. C.

Dame, R. F. (1979). The abundance, diversity and biomass of macrobenthos on North Inlet, South Carolina, intertidal oyster reefs. Proc. nat. Shellfish Ass. 69:6-10

Dame, R. F., Vernberg, F. J. (1978). The influence of constant and cyclic acclimation temperatures on the metabolic rates of Panopeus herbstii and Uca pugilator. Biol. Bull mar biol. Lab., Woods Hole 154; 188-197

Dame, R. F., Zingmark, R., Stevenson, L. H., Nelson, D. (1980). Filter feeder coupling between the estuarine water column and benthic subsystems. In: Kennedy, V. C. (ed.) Estuarine perspectives. Academic Press, New York, pp. $521-526$
Finn, J. T (1976). Measures of ecosystem structure and function derived from analysis of flows. J theor Biol. 56: 363-380

Gerlach, S. A. (1971). On the importance of marine mejofauna for benthos communities. Oecologia (Berl.) 6: 176-190

Hannon, B. (1973). The structure of ecosystems. J. Theor. Biol. 41: $535-546$

Hedgpeth, J. (ed.) (1957). Treatise on marine ecology and paleoecology (Mem. geol. Soc. Am. 67). The Geological Society of America, New York

Hutchinson, G. E. (1948). Circular causal systems in ecology. Ann. N.Y. Acad. Sci. 50: 221-245

Kitchell, J. F., O'Neill, R. V., Webb, D., Gollipp, G. W., Bartell, S. M., Koonce, J. F., Augmus, B. S. (1979). Consumer regulation of nutrient cycling. Bioscience 29 : 28-34

Lindeman, R. L. (1942). The trophic-dynamic aspect of ecology. Ecology 23: 399-418

Lotka, A. J. (1925). Elements of physical biology, Williams and Wilkins, Baltimore

Mackin, J. (1962). Oyster diseases caused by Dermocystidium marinum and other microorganisms in Louisiana. Pub. Inst. Mar. Sci. Univ. Texas 7: 132-229

Möbius, K. (1877). Die Auster und die Austernwirtschaft, Wiegundt, Hempel und Parey, Berlin

Odum, H. T., Pinkerton, R. C. (1955). Time's speed regulator: the optimum efficiency for maximum power output in physical and biological systems. Am. Sci. 43: 331-343

O'Neill, R. (1976). Ecosystem persistence and heterotrophic regulation. Ecology 57: 1244-1253

Patten, B. C. (1979). Energy environments in ecosystems. In: Fazzolare, R. A., Smith, C. B. (eds) Energy use management, Vol. III. Pergamon Press, New York, pp. 853-857

Patten, B. C., Bosserman, R. W., Finn, J. T., Cale, W. G. (1976). Propagation of cause in ecosystems. In: Patten, B. C. (ed.) System analysis and simulation in ecology, Vol. IV. Academic Press, New York, pp. 457-579

Rheinheimer, G. (1977). Microbial ecology of a brackish water environment. Springer-Verlag, New York

Sikora, J. P., Sikora, W. B., Erkenbrecher, C. W., Coull, B. C. (1977). Significance of ATP, carbon, and caloric content of meiobenthic nematodes in partitioning benthic biomass. Mar Biol. 44: 7-14

Simon, V M. (1976). Microbial biomass in high marsh sediments of North Inlet Estuary, South Carolina. M. S. thesis, University of South Carolina, Columbia

Teal, J., Kanwisher, J. (1961). Gas exchange in a Georgia salt marsh. J. exp. Bot. 17: 355-361

Tenore, K., Dunstan, W (1973). Comparison of feeding and biodeposition of three bivalves at different food levels. Mar. Biol. 21: 190-195

Tenore, K., Gopalan, U. K. (1974). Feeding efficiencies of the polychaete Nereis virens cultured on hard-clam tissue and oyster detritus. J Fish. Res. Bd Can. 31 1675-1678

Thayer, G. W., Schaaf, W., Angelovic, J., LaCrois, M. (1973). Caloric measurements of some estuarine organisms. Fish Bull. 71: 289-296

Vernberg, W. B., Coull, B. C. (1974). Respiration of an intertidal ciliate and benthic energy relationships. Oecologia (Berl.) 16: 259-264

Virnstein, R. W (1979). Predation on estuarine infauna: Response patterns of component species. Estuaries 2: $69-86$

Wieser, W., Kanwisher, J. (1961). Ecological and physiological studies on marine nematodes from a small salt marsh near Woods Hole, Mass. Limnol. Oceanogr 6: 262-270 